\title{
White lupine as a way to improve the biochemical and economic indicators of diets of non-great apes
}

\author{
N.V. Gaponov ${ }^{1,2, *}$, J.L. Nersesyan ${ }^{2}$, and O.P. Neverova ${ }^{3}$ \\ ${ }^{1}$ All-Russian Lupine Scientific Research Institute - Branch of the Federal Williams Research Center of \\ Forage Production \& Agroecology, 241524 Bryansk region, p/o Michurinskiy, Berezovaya str., 2, \\ Russia \\ ${ }^{2}$ FSBI Scientific «Research Institute of Medical Primatology», 354376, World st., 177, Krasnodar \\ Territory, Sochi, Russia \\ ${ }^{3}$ Ural State Agrarian University, 620075 Karl Liebknecht str., 42, Yekaterinburg, Russia
}

\begin{abstract}
The article is devoted to the current problem of providing rations with a source of protein with a high biological value. Such a source is suggested to be white lupine and products of its processing. Since, white lupine exceeds the protein content of peas, vetch and other legumes by more than $10 \%$. And the significant content of fat in its composition allows, when using it, to reduce or completely abandon the use of sunflower oil in the diet. The use of white lupine allowed the experimental primates to use the food efficiently. The lowest costs were observed in the 3-test group. Energy costs were lower by $48.80 \%$, crude protein by $47.22 \%$ and digestible protein by $51.3 \%$. In the 2-experimental group, the costs of metabolic energy, crude protein and digestible protein were lower by $25.00 \%, 26.38 \%$ and 39.20 , respectively. Thus, the inclusion of white lupine in the structure of the diet helps to improve the nutritional value of rations, to reduce the cost of nutrients and feed, improving the economic indicators of the maintenance of primates.
\end{abstract}

\section{Introduction}

Recently, the increasing attention of feed manufacturers has been paid to the white lupine and lupin-based products, which was viewed as a source of proteins with a high biological value. The protein content of the white lupine has $10 \%$ than that of peas, vetch, and other legumes (Fabaceae, L.) [12].

The protein composition that contains an adequate proportion of the amino acids for the animal feed, of the narrow-leaved lupine seeds is $33-37 \%$, of the white lupine seeds is $34-$ $39 \%$, of the new type of the yellow lupine seeds Bulat is $39-44 \%$ [10].

The lupine, especially white lupine contains not only the protein, but also a large amount of fat, which allows to reduce the use of the sunflower oil in the animal diet to a significant

\footnotetext{
* Corresponding author: nv.1000@bk.ru
} 
level. This markedly distinguishes it from soybean and sunflower meal and cakes, currently used as the main sources of the fodder protein. The protein yield of the white lupine is higher as compared to other types of lupine $[10,4]$.

The lupine grain contains large amount of protein with the high biological value and is a valuable concentrate used in the form of the protein additives in the fodder preparations. It is characterised by the complete absence of the trypsin inhibitors. The new types of lupine have low content of alkaloids in its grain $(0.06-0.132 \%)$, which is significantly lower than the maximum permissible values $[5,6]$.

It is generally recommended to carry out the pre-treatment of the of the native lupine to increase the feed value and improve the digestibility. One possible way to improve the fodder quality of the lupine grain is the thermal or barothermal treatment, that involves the processes of destruction of the cellulose-lignin formations, dextrinization of the starch and inactivation of anti-nutrients occurs. The product acquires a microporous structure with improved taste and increased digestibility $[2,17]$.

The granulation technology of the compound feed ensures the steady mix uniformity, sanitary and hygienic standards improvement, nutritional value increase, the shelf-life extension, and the minimisation of losses during the transportation and product distribution [11].

Due to its high protein content, biological value, and the minimum amount of the antinutrients in the fodder the lupine is now widely recognised as a one of the most valuable legumes.

With the advent of the import substitution of the fodder protein in Russia and the higher demand for the lupine share of lupine in the sown areas structure of the Russian Federation has increased. This allows to establish the adequate supply of the high-quality protein for the fodder manufacturers $[5,10]$.

Many studies have been focused on the use of the lupine protein in the compound cattle, poultry, and fish feed. Yet, there is lack of data on the use of the white lupine in complete compound feed for the primates.

Although the gastrointestinal tract specification varies in the different orders of mammals, the primates GI tract remains unique. The digestive tract structure characteristics vary even within one specie. For instance, Macaca mulatta has mixed type of diet: Frugivores, Omnivores [13, 14, 19].

Most non-human primates commonly used in laboratory research fall into this category due to their mixed diet and the human-like feeding pattern which make them more adaptable to housing. The complete feed development for non-human primates required careful research of the existing literature on the feeding ecology of the primates in the wild.

The previously obtained data was used to record foraging and feeding behaviour in their natural habitat. The careful study of their feed ecology may advance the complete compound feed preparation. Based on the recent studies the process of the ration formulation from agrocenoses cultivated feed capable to replace the regular feed in the natural habitat has begun.

The aim of this study was to examine the effect of the white lupine (Lupinus albus) on the complete feed nutritional value for the rhesus macaques (Macaca mulatta) and to evaluate the cost effectiveness of the complete feed formulated, its energy content, and other nutrients.

\section{Materials and methods}

The study was performed (M. mulatta) at Research Institute of Medical Primatology (FSBSI "NII MP") on the male rhesus monkeys (M. mulatta). The groups were formed using 
analogous pairs method and composed of 3 groups of 4 animals in each group with average age of 10 years. All observations were carried out in vivarium and lasted 35 days. The experiment was carried out according to the generally accepted research methods $[3,7,9$, 19].

The rhesus macaques (M. mulatta) were fed a complete feed with nutritional value calculated according to the feeding standards. The calculations of the nutrient concentration were based on the previous non-human primate studies $[15,16,18,19]$.

The experimental design is summarized in Table 1.

Table 1. Experiment summary.

\begin{tabular}{|c|c|l|}
\hline Groups & $\begin{array}{c}\text { Number } \\
\text { of Species }\end{array}$ & \multicolumn{1}{|c|}{ Feed Composition } \\
\hline $\begin{array}{c}\text { I } \\
\text { Control }\end{array}$ & 4 & Complete Feed (CF) \\
\hline $\begin{array}{c}\text { II } \\
\text { Experimental }\end{array}$ & 4 & $\begin{array}{l}\text { CF - lupin content 10\%. Soybean and sunflower meal substituted } \\
\text { by native lupine by } 50 \% .\end{array}$ \\
\hline $\begin{array}{c}\text { III } \\
\text { Experimental }\end{array}$ & 4 & $\begin{array}{l}\text { CF - lupine content 20\%. Soybean, sunflower, and corn cake } \\
\text { substituted by native lupin by 50\%, fish meal and milk powder } \\
\text { substituted by } 50 \% .\end{array}$ \\
\hline
\end{tabular}

The control group received full-fat balanced feed. The primates of the Group II received the complete feed with $10 \%$ native white lupine substitution. For the group III primates the complete feed was lupine substituted by $20 \%$.

The physiological experiment designed to assess the nutrient consumption and the growth rate of the male rhesus macaques was divided into two periods:

The preparatory period ( 5 days), which purpose was to eliminate the effect of the previous diet and to get the primates accustomed to the cage housing.

The experimental period ( 5 days), during this period the food intake and excreta were carefully recorded. The feeding schedule for the experimental group was the same as for the control group.

Due to the nutrient content of the feed residues did not correspond to that of the actual feed, it was decided to calculate feed residues daily and contribute $5 \%$ of it to the formation of the average sample, which was then analysed to determine its nutrient content. The data obtained was used to calculate the total feed and protein consumption for the experiment.

The results were processed using GraphPad Prizm 8.0 software (USA) and expressed as a mean value \pm standard error. Statistical significances were analysed using one-way ANOVA with Tukey and Sidak multiple-comparison post-hoc correction method at the significance level of $\mathrm{p}<0.05$.

\section{Results and Discussion}

The effectiveness of the diet is affected by the feed volume and quality, nutritional value, and the ratio of the nutrients. The high-quality ration must contain the various types of forages and supplements. The feeds variability prevents nutritional deficiency and makes diet more balanced and nutritionally complete (Table 2 ). 
Table 2. Nutritional value of the complete feed.

\begin{tabular}{|c|c|c|c|}
\hline Values & $\begin{array}{c}\text { CF } \\
\text { Complete Feed }\end{array}$ & $\begin{array}{c}\text { CF } \\
\text { White Lupine - } \\
10 \%\end{array}$ & $\begin{array}{c}\text { CF } \\
\text { White Lupine }-20 \%\end{array}$ \\
\hline $\mathrm{ME}(M J)$ & 12.30 & 12.30 & 12.30 \\
\hline Dry matter, (g) & 792.50 & 795.67 & 805.10 \\
\hline Crude protein $(\mathrm{g})$ & 229.32 & 228.26 & 228.09 \\
\hline $\mathrm{DP}(\mathrm{g})$ & 206.00 & 195.68 & 196.78 \\
\hline Lysin (g) & 96.50 & 96.37 & 96.20 \\
\hline Methionine + cysteine $(\mathrm{g})$ & 6.53 & 6.68 & 7.19 \\
\hline Tryptophan $(\mathrm{g})$ & 3.35 & 3.09 & 2.94 \\
\hline Crude fat $(\mathrm{g})$ & 37.87 & 32.12 & 27.35 \\
\hline Crude fiber $(\mathrm{g})$ & 31.29 & 29.98 & 35.87 \\
\hline NFE (g) & 244.55 & 235.29 & 212.26 \\
\hline Calcium (g) & 11.99 & 15.21 & 16.79 \\
\hline Phosphorous (g) & 5.07 & 4.24 & 3.06 \\
\hline Magnesium (g) & 2.80 & 2.85 & 3.07 \\
\hline Potassium (g) & 4.61 & 3.51 & 2.85 \\
\hline Sulphur (g) & 2.48 & 3.22 & 4.16 \\
\hline Iron $(\mathrm{g})$ & 54.51 & 33.68 & 27.72 \\
\hline Copper (g) & 18.20 & 23.05 & 28.76 \\
\hline Zink (mg) & 21.27 & 17.74 & 13.72 \\
\hline Manganese (mg) & 19.75 & 20.71 & 24.01 \\
\hline Cobalt (mg) & 16.08 & 17.24 & 18.40 \\
\hline Iodine (mg) & 0.28 & 0.26 & 0.18 \\
\hline Carotin (mg) & 0.64 & 0.47 & 0.38 \\
\hline
\end{tabular}

Notes: DP - Digestible Protein, NFE - nitrogen-free extract (NFE), ME - metabolizable energy

The control group received a complete balanced feed containing $34.10 \%$ of wheat for the duration of 35 days. Soybean meal, sunflower meal, corn, and corn gluten constituted $10 \%$ of the mixed fodder. The protein sources were $6 \%$ fish meal, $2 \%$ egg powder and $4 \%$ milk powder. The ration was balanced by $0.3 \%$ of sunflower oil and $6 \%$ of sugar. The calcium and phosphorous deficiencies were adjusted by $3 \%$ by tricalcium phosphate and 3.6 feed pre-mix.

The group II food ration was identical to that of the control group except for the $10 \%$ of the white lupine addition. As the result the high protein plant-based feed, containing soybean and sunflower meal was substituted by the white lupine by $50 \%$. The ration composition of the other feed types was also identical to the control group.

For the group III, the plant and animal sourced high-protein feeds were replaced by the white lupine, which comprised $20 \%$ of the feed composition. The white lupine replaced the soybean meal by $50 \%$, sunflower meal by $50 \%$, corn by $50 \%$ wheat by $0.3 \%$ and the constituents of animal feed such as fish meal and dry milk powder by $50 \%$. Therefore, the addition of the white lupine resulted in normalisation of the metabolizable energy level and the reduction of the vegetable oil content by $1.2 \%$. The rest of the experimental ration ingredients corresponded to that of the control group ration.

It is widely known that the developing organisms respond to the altered feeding conditions by changing the growth rate. Hence the beneficial effect of lupine may be defined by the increase in body mass. In our experiment the white lupine positively affected the body weight gain. For instance, the weight gain in the experimental group II and III was $33.3 \%$ and $95 \%$ higher respectively compare to the control group.

One of the most important principles of the primate care is to ensure the feed cost is defined by the growth of animal e.g. to calculate the amount of metabolizable energy and 
crude protein required to upkeep 1 head of rhesus macaque over the course of the experiment.

Table 3. The feed cost per 1 head over the course of the experiment $(M \pm n)$.

\begin{tabular}{|c|c|c|c|}
\hline \multirow[b]{2}{*}{ Indicators } & \multicolumn{3}{|c|}{ Groups } \\
\hline & Control & 2- Experiments & 3- Experimental \\
\hline Weight (kg) & & & \\
\hline Start & $9.85 \pm 1.25$ & $9.25 \pm 0.07$ & $10.27 \pm 0.85$ \\
\hline End & $10.30 \pm 1.16$ & $9.85 \pm 0.71$ & $11.15 \pm 1.18^{* *}$ \\
\hline Growth $(\mathrm{kg})$ & $0.45 \pm 0.14$ & $0.60 \pm 0.13 *$ & $0.88 \pm 0.33$ \\
\hline$\%$ to control & 100 & 33.30 & 95.00 \\
\hline Feed cost. $1 \mathrm{~kg} / \mathrm{rub}$ & 52.17 & 49.90 & 44.61 \\
\hline$\%$ to control & 100 & -4.35 & -14.49 \\
\hline \multicolumn{4}{|l|}{ Cost per 1 head. } \\
\hline MJ & 956.70 & 717.5 & 489.21 \\
\hline$\%$ to control & 100 & -25.00 & -48.80 \\
\hline Crude protein $(\mathrm{kg})$ & 18.00 & 13.25 & 9.50 \\
\hline$\%$ to control & 100 & -26.38 & -47.22 \\
\hline Digestible protein $(\mathrm{kg})$ & 16.10 & 9.78 & 7.83 \\
\hline$\%$ to control & 100 & -39.20 & -51.30 \\
\hline
\end{tabular}

Note: data $*-\mathrm{p}<0,05,{ }^{*}-\mathrm{p}<0,01$, compare to control group. Data were expressed as mean values \pm standard error.

Data in Table 3 demonstrated the white lupine incorporated into the diet improved the effectiveness of the feed utilisation by the experimental animals. The rhesus-macaque males of all groups spend similar amount of feed and nutrients per head per day, yet the body weight gain cost was lower in experimental groups. Lupin positively influenced the cost of metabolizable energy, crude, and digestible protein. The lowest cost was observed in a Group III. The energy input was reduced to $48.8 \%$, crude protein to $47.22 \%$ and digestible protein to $51.3 \%$. In Group II the metabolizable energy, crude and digestible protein consumption was lowered by $25.0 \%, 26.38 \%$ and $39.2 \%$ correspondingly.

Hence the incorporation of the white lupine into the male rhesus macaque diet helps to reduce the cost of the nutrient and feed per animal.

Table 7. The cost of complete feed ( $\mathrm{kg} / \mathrm{rub})$.

\begin{tabular}{|l|c|c|c|c|c|c|}
\hline \multirow{2}{*}{ Indicators } & \multicolumn{6}{|c|}{ Groups } \\
\cline { 2 - 7 } & \multicolumn{1}{|c|}{ - Experimental } & \multicolumn{2}{c|}{ - Experimental } & \multicolumn{2}{c|}{3 - Experimental } \\
\cline { 2 - 7 } & $\mathrm{g}$ & $\mathrm{rub}$ & $\mathrm{g}$ & $\mathrm{rub}$ & $\mathrm{g}$ & rub \\
\hline Soybean cake & 95 & 6.12 & 41 & 2.64 & 40 & 2.58 \\
\hline Corn & 100 & 2.66 & 100 & 2.66 & 51 & 1.36 \\
\hline Wheat & 331 & 8.20 & 335 & 8.30 & 337 & 8.35 \\
\hline Dry milk powder & 30 & 7.26 & 30 & 7.26 & 10 & 2.42 \\
\hline Sunflower cake & 110 & 2.94 & 50 & 1.34 & 50 & 1.34 \\
\hline Corn gluten & 90 & 5.55 & 90 & 5.55 & 90 & 5.55 \\
\hline Sugar & 85 & 3.38 & 85 & 3.38 & 84 & 3.34 \\
\hline Egg powder & 10 & 3.49 & 10 & 3.49 & 10 & 3.49 \\
\hline Sunflower oil & 11 & 0.81 & 11 & 0.81 & 10 & 0.73 \\
\hline
\end{tabular}




\begin{tabular}{|l|c|c|c|c|c|c|}
\hline Premix & 36 & 3.83 & 36 & 3.83 & 36 & 3.83 \\
\hline $\begin{array}{l}\text { Vitamin C } \\
\text { stabiliser }\end{array}$ & 6 & 4.05 & 6 & 4.05 & 6 & 4.05 \\
\hline $\begin{array}{l}\text { Tricalcium } \\
\text { phosphate }\end{array}$ & 30 & 0.74 & 30 & 0.74 & 30 & 0.74 \\
\hline Salt & 4 & 0.04 & 4 & 0.04 & 4 & 0.04 \\
\hline Fish meal & 62 & 3.10 & 61 & 3.05 & 30 & 1.50 \\
\hline White lupin & - & - & 111 & 2.78 & 212 & 5.30 \\
\hline \multicolumn{1}{|c|}{ Total } & 1000 & $\mathbf{5 2 . 1 7}$ & 1000 & $\mathbf{4 9 . 9 0}$ & 1000 & $\mathbf{4 4 . 6 1}$ \\
\hline
\end{tabular}

The main component of the control group feed was fodder wheat, which accounted for $34.1 \%(331 \mathrm{~g})$ for $1 \mathrm{~kg}$ of feed. The price stood at $8.2 \mathrm{rub}$. The protein sources of the high protein feed were soybean cake, which accounted for $10 \%(6.12 \mathrm{rub})$ of the complete feed, sunflower meal for $10 \%$ (2.94 rub) and corn gluten for 10\% (5.55 rub). The cost of highprotein animal fodder was the highest among the other animal feeds and despite of its low content in a feed mixes the price remained high. The dry low-fat milk content was $4 \%(7.26$ rub), egg powder 2\% (3.49 rub) and fish meal 6\% (3.10 rub). The price of the complete feed of the control group was $52.17 \mathrm{rub}$ per $1 \mathrm{~kg}$.

For the group II, the complete feed formulation was altered by $50 \%$ replacing the soybean and sunflower meal by lupin. The rest of the feed composition and supplementation was identical to the control group, with cost of 49.9 rub per $1 \mathrm{~kg}$ of feed.

In the experimental group III, the formulation of the feed mixed was altered to a significant level. M. mulatta received the complete feed, where the high protein plant and animal-based constituents were replaced by lupine. The soybean meal, sunflower meal and corn were substituted by $50 \%$ of lupin. The animal-based feed containing fish meal and dry milk powder was replaced by $50 \%$ of lupine. Subsequently the white lupin constituted $20 \%$ of the complete feed formulation with the cost of $44.61 \mathrm{rub}$ per $1 \mathrm{~kg}$.

The result of the incorporation of the white lupin into the group II feed composition was a reduction of $1 \mathrm{~kg}$ feed cost relative to the control group by $2.27 \mathrm{rub}$ and 7.56 for the group III.

The cost of metabolizable energy in the rations depends on the feed cost and nutritional value of the feed. The cost of $1 \mathrm{MJ}$ in control group was $3.95 \mathrm{rub}$, in group II was 3.78 rub. The lowest cost of $1 \mathrm{MJ}$ which totalled only $3.37 \mathrm{rub}$ was in the experimental group III.

The protein cost followed the same pattern. The lowest cost of 0.19 rub per $1 \mathrm{~g}$ was in the group III. The highest cost $(0.23 \mathrm{rub})$ was in the control group. In the group II the protein cost reached 0.21 rub per $1 \mathrm{~g}$.

\section{Conclusion}

The data collected over the course of experiment confirms the incorporation of the white lupine (Lupinus Albinus) in the complete feed formulations for the non-human primates facilitates the feed cost reduction and therefore improves the nutritional value of the feed. The use of the white lupine helps to lower the cost of primates housing and increase profitability. Hence the use of white lupine in primate diet is economically feasible.

\section{References}

1. P.A. Ageeva, N.A. Pochutina, Novye sorta lyupina, tekhnologiya ih vyrashchivaniya $i$ pererabotki, adaptaciya $v$ sel'skom hozyajstve $i$ zhivotnovodstve, 47-59 (Bryansk, 2017) 
2. A.I. Artyuhov, N.V. Gaponov, Energy sugar concentrate and method for its preparation, Patent for invention RU 2461211 C2, 20.09.2012. Application No. 2010144896/13 dated 02.11.2010

3. P.I. Viktorov, V.K. Men'kin, Methodology and organization of zootechnical experiments, 112 (M., Agropromizdat, 1991)

4. N.V. Gaponov, Innovations and Food Safety, 4(30), 101-107 (2020)

5. N.V. Gaponov, S.A. Pigaryova, Problemy biologii produktivnyh zhivotnyh, 3, 47-53 (2010)

6. N.V. Gaponov, E.I. Slezko, A.A. Men'kova, Veterinariya i kormlenie, 3, 26-28 (2012)

7. A.P. Kalashnikov, Normy i raciony kormleniya sel'skohozyajstvennyh zhivotnyh, 456 (M., 2003)

8. M.I. Lukashevich, M.V. Zaharova, T.V. Sviridenko, N.I. Haraborkina, L.V. Troshina, Novye sorta lyupina, tekhnologiya ih vyrashchivaniya i pererabotki, adaptaciya $v$ sel'skom hozyajstve i zhivotnovodstve, 59-66 (Bryansk, 2017)

9. A.I. Ovsyannikov, Osnovy opytnogo dela v zhivotnovodstve, 304 (M., Kolos, 1967

10. V.I. Ruckaya, A.E. Sorokin, Adaptivnoe kormoproizvodstvo, 1, 6-11 (2019)

11. I.P. Takunov, Lyupin v zemledelii Rossii, 372 (Bryansk «Pridesen'e», 1996)

12. G.I. Taranuho, Lyupin - kul'tura bol'shih vozmozhnostej. Problemy deficita rastitel'nogo belka i puti ih preodoleniya, 73-83 (Minsk, Belorusskaya nauka, 2006)

13. J. Altmann, Observational study of behavior, 227-267 (Behaviour, 1974)

14. D.J. Chivers, C.M. Hladik, Morphology of the gastrointestinal tract of primates, comparisons with other mammals in relation to diet. J. Morphol, 337-386 (1980)

15. J.J. Knapka, Factors Affecting the Required Concentrations of Nutrients in the Diet. Anime Lab, 47-50 (2000)

16. N.V. Gaponov, T.N. Lenkova, Innovacionnye nauchnye issledovaniya, 12, 1(2), 5-14 (2020)

17. N.V. Gaponov, O.P. Neverova, O.V. Gorelik, A.V. Stepanov, E3S Web of Conferences 222, 02006 (2020)

18. N.V. Gaponov, G.L. Yagovenko, A.N. Stepanova, O.P. Neverova, O.V. Gorelik, E3S Web of Conferences 222, 02005 (2020)

19. E.U. Duane, E.A. Mary, M.A. Lynne, L.C. Nancy, S.E. Mark, Nutrient Requirements of Nonhuman Primates Second Revised Edition, 2003, Ad hoc committee on nonhuman primate nutrition, committee on animal nutrition, board on agriculture and natural resources, The national academies press Washington, D.C., 286 (2003) ISBN 978-0309-06989-2, DOI 10.17226/9826 